\title{
PENDEKATAN MUTU KARET ALAM SIR 3L, SIR 5, SIR 10, SIR 20 DAN RSS TERHADAP MUTU KARET SINTETISPOLYCHLOROPRENE (CR) - NEOPRENE DALAM PENGGUNAAN KARET COMPOUND ELASTOMERIC BEARING PAD JEMBATAN
}

\author{
Approach to Natural Rubber Quality SIR 3L, SIR 5, SIR 10, SIR 20 and RSS on The \\ Quality Of Rubber Synthetic Polychloroprene (CR) - Neoprened in Use of Rubber \\ Compound Elastomeric Bearing in Bridge
}

\author{
Herbet Erwin F.Manurung, Brando Alvonso, Yulia Saptini, Juandika, dan Agung Sedayu \\ Balai Pengujian Mutu Barang, Kementerian Perdagangan \\ Jl. Raya Bogor, Km.26, Ciracas, Jakarta Timur \\ e-mail: herbeterwin.777@gmail.com
}

\begin{abstract}
ABSTRAK
Penyerapan pengunaan karet alam sebagai bentuk hilirisasi produk karet dengan penggunaan karet tersebut pada infrastruktur dapat meningkatkan nilai ekonomis serta memberikan suatu kontribusi peningkatan harga karet yang dapat meningkatkan pendapatan petani karet. Penggunaa jenis karet alam SIR 3L, SIR 5, SIR 10, SIR 20 dan karet RSS sebagai bahan kompon karet alam untuk elastomeric bearing pad jembatan dengan memperhatikan karakteristik fisika properties untuk memenuhi persaratan sesuai dengan standar SNI 3967:2008 dibandingkan dengan kompon karet berbahan karet sintetis seperti karet Neoprene. Hasil pengujian fisika properties seperti kekerasan, kuat tarik, perpanjangan putus, ageing test, kuat sobek, low temperature test, abrasi dan ozon test memperlihatkan bahwa karet alam sangat memenuhi sebagai bahan kompon karet peruntukan elastomeric bearing pad pada jembatan dengan keunggulan dibeberapa karakteristik tertentu, sehingga dapat mengurangi penggunaan karet sintetis. Untuk lebih dapat menghasilkan karakteristik kompon karet alam yang memenuhi keseluruhan parameter fisika properties perlu dilakukan suatu uji dari beberapa kombinasi campuran tipe karet alam atau dengan campuran karet sintetis.
\end{abstract}

Kata kunci: karet alam, compound, fisika properties, elastomeric bearing jembatan

\section{Abstrac}

The absorption of the use of natural rubber as a form of downstreaming of rubber products with the use of rubber in infrastructure can increase economic value and contribute to an increase in rubber prices that can increase the income of rubber farmers. The use of natural rubber SIR 3L, SIR 5, SIR 10, SIR 20 and RSS rubber as natural rubber compound for elastomeric bearing pad bridges by taking into account the characteristics of physical properties to meet the requirements according to SNI 3967: 2008 compared to rubber compound made from synthetic rubber like Neoprene rubber. The results of physical properties testing such as hardness, tensile strength, elongation at break, aging test, tear strength, low temperature test, abrasion and ozone test show that natural rubber is very satisfying as an elastomeric bearing pad compound on the bridge with advantages in certain characteristics, so can reduce the use of synthetic rubber. To be able to produce the characteristics of natural rubber compounds that meet all the parameters of physical properties, it is necessary to test a combination of various types of natural rubber mixtures or with synthetic rubber mixtures.

Keywords: natural rubber, compound, physics properties, elastomeric bearing bridge

\section{PENDAHULUAN}

Pemerintah melalui instruksi presiden Republik Indonesia yang sedang aktif melakukan pembangunan infrastruktur menjadi momentum untuk melakukan perbaikan harga karet melalui penyerapan karet alam untuk penggunaan infrastruk jalanan seperti penggunaan campuran karet alam pada aspal jalanan, dokvender pelabuhan, dan beraing pad untuk jembatan. Seperti kita ketahui, saat ini banyak pembangunan infrastruktur jalan yang sedang dibangun dengan laying, ataupun infrastruktur transportasi seperti jalan tol laying, LRT dan
MRT layang yang banyak mempergunakan bearing pad sebagai peredam atau pensuport jembatan tersebut.

Saat ini banyak bearing pad jembatan yang mempergunakan bahan baku karet sintetis dengan pertimbangan harga yang tidak terlalu mahal dan memberikan sifat fisika yang cukup baik seperti karakterisitik parameter kekerasan, ketahanan terhadap ageing test dan paparan lingkungan dan ozon, dan parameter-parameter lainnya. Parameterparameter fisika tersebut merupakan parameter yang sangat penting dalam aplikasi pengunaan bearing pad jembatan, dimana dapat memberikan umur pakai yang lebih 
lama. Terkait dengan hal tersebut, peniliti perlu untuk melihat kembali sejauh mana perbandingan kekuatan bearing pad dengan bahan baku karet alam seperti SIR 3L, SIR 5, SIR 10, SIR 20 dan karet RSS yang merupakan karet unggulan produksi dalam negeri, sehingga dapat mendukung penyerapan penggunaan karet alam yang dapat meningkatkan harga karet sehingga dapat memberikan nilai ke ekonomisan terhadap petani karet rakyat.

Penelitian ini bertujuan untuk mempelajari pengaruh jenis karet alam seperti SIR 3L, SIR 5, SIR 10, SIR 20 dan karet RSS terhadap mutu kompon karet bearing pad terhadap parameter-parameter uji fisika karet. Penelitian ini juga mempelajari perbandingan mutu karakteristik karet alam terhadap mutu karkteristik karet sintetis.

\section{TINJAUAN PUSTAKA}

\section{Pengertian Karet}

Karet merupakan politerpena yang disintesis secara alami melalui polimerisasi enzimatik isopentilpirofosfat. Unit ulangnya adalah sebagaimana 1,4-poliisoprena.

\section{Lateks Karet}

Lateks adalah getah kental, seringkali mirip susu yang dihasilkan banyak tumbuhan dan membeku ketika terkena udara bebas. Lateks terdiri atas partikel karet dan bahan bukan karet (non-rubber) yang terdispersi di dalam air.

\section{Bokar Karet}

Bahan olah karet adalah lateks kebun serta gumpalan lateks kebun yang diperoleh dari pohon karet. Yang termasuk bahan olah karet adalah lateks kebun, sheet angin, slab tipis dan lump segar yang dibagi berdasarkan pengolahannya.

\section{Jenis Karet}

Jenis Karet Menurut Syakir dkk (2010) ada dua jenis karet secara umum yaitu karet alam dan karet sintetis. Setiap jenis karet memiliki karakteristik yang berbeda sehingga keberadaannya yang saling melengkapi. Saat ini karet yang digunakan di industri terdiri dari karet alam dan karet sintetis.

\section{Sifat-sifat Karet Alam}

Karet alam (polyisoprene) termasuk kedalam elastomer yaitu bahan yang dapat direnggangkan dan dapat kembali seperti bentuk semula. Karet alam memiliki berbagai keunggulan dibanding karet sintetik, terutama dalam hal elastisitas, daya redam getaran, sifat lekuk lentur dan umur kelelahan. Menurut Andriyanti (2010) data-data sifat fisis karet alam yaitu: setelah penggumpalan warnanya putih hingga coklat, elastisitas semakin bertambah setelah karet dipanaskan, tidak dapat larut dalam air, sensitif terhadap adanya perubahan temperature. Sementara itu terdapat juga sifat kimia karet Alam yaitu: udara dapat menyebabkan karet teroksidasi, karet alam akan berubah menjadi $\mathrm{CO} 2$ dan $\mathrm{H} 2 \mathrm{O}$ bila dibakar.

\section{Jenis-jenis Karet Alam}

Jenis-jenis karet alam yang dikenal luas adalah: Karet alam SIR 3CV, 3L, 3WV, SIR 5, SIR 10 dan SIR-20 dan karet konvensional

\section{Karet neoprene}

Karet neoprene adalah karet sintetis yang terbuat dari proses polymerisasi pada chloroprene dan seringkali disebut dengan polychloroprene. Keungulantahan terhadap suhu atau cuaca, terhadap minyak dan rendaman air, terhadap solvent atau pelarut dan masih ada beberapa kelebihan bahan neoprene yang lainnya.

\section{Kompon karet}

Kompon karet adalah campuran antara karet alam dengan bahan-bahan kimi yang ditentukan komposisinya dan pencampurannya dilakukan dengan cara pengilingan pada suhu $70 \pm 5^{\circ} \mathrm{C}$, kemudia dilanjutkan pembentukan vulkanisasi. Komposisi kompon karet berbeda-beda tergantung pada barang jadi karet yang akan dibuat.

\section{VulkaniSIR | Vulkanisasi}

Sistem vulkanisasi / vulkaniSIR sangat mempengaruhi sifat fisik dan sifat pengusangan barang karet. Karakterisasi vulkanisasi memberikan informasi mengenai waktu pravulkanisasi, waktu pemasangan, laju vulkanisasi dan modulus torsi untuk sistem vulkanisasi yang diberikan pada suhu pemasakan yang diinginkan.

\section{Kandungan Kompon}

Terdapat lima kategori utama kandungan kompon. Kelima kandungan utama tersebut dalam kompon elastomer diantaranya adalah: kurativ untuk pembentukan crosslink atau 
jaringan, anti degadarasi untuk melindungi, filler untuk pengguat dan additive untuk mempermudah dalam proses pembuatan.

\section{Density}

pengujian untuk menentukan tingkat kerapatan bahan, yang sangat dipengaruhi oleh jenis dan komposisi bahan. Density secara umum dipergunakan untuk mengukur material polimer untuk mengetahui variasi struktur dan komposisi, bisa juga dipergunakan untuk mengetahui keseragaman material untuk penerapan aplikasi pada berbagai jenis produk.

\section{Ketahanan terhadap abrasi}

Ketahanan kikis/abrasi adalah kesangupan karet bertahan terhadap gesekan dengan benda lain.. Semakin keras sifat karet maka akan semakin tahan terhadap ketahan pengikisan dan sebaliknya semakin lunak karet maka akan semakin rentan terhadap ketahanan pengikisan.

\section{Kekerasan (Sore A)}

Uji kekerasan dilakukan untuk mengetahui besarnya kekerasan vulkanisat karet, dilakukan dengan kekuatan penekanan tertentu. Nilai kekerasana kompon karet semakin besar menunjukkan bahwa kompon karet semakin tidak elastis. Semakin tinggi suhu dan lama pengusanagan akan menaikkan nilai kekerasan kompon karet setelah pengusangan dibanding sebelum pengusangan.

\section{Kuat Tarik}

Kuat tarik merupakan pengujian fisika karet yang terpenting dan paling sering dilakukan dengan pengujian ini pula dapat ditetapkan waktu vulkanisasi optimum suatu kompon dan pengaruh pengusangan pada suatu vulkanisasi, selain itu juga pengujian ini menggambarkan kekuatan dan kekenyalan karet. Nilai kuat tarik semakin besar, menunjukkan bahwa kompon karet semakin elastis.

\section{Perpanjangan Putus (\%)}

Perpanjangan putus merupakan pertambahan panjang suatu potongan uji kompon karet bila diregangkan sampai putus, dinyatakan dengan persentase dari panjang potongan uji sebelum diregangkan. Banyaknya ikatan yang terbentuk akan mengurangi keleluasan gerak rantai polimer, menyebabkan viskositas kompon meningkat, kompon menjadi kaku, keras dan elastisitasnya turun (Chuayjuljit et al., 201; Phrommedetch dan Pattamaprom, 201).

\section{Kuat Sobek}

Pengujian ini bertujuan untuk mengetahui kekuatan sobek dari material karet dengan mengukur tenaga yang dibutuhkan untuk menyobek contoh uji, yang sebelumnya sudah diberi sobekan.Nilai kekuatan yang diperlukan untuk merobek material dan membuat retakan berlanjut sampai gagal.Graves (atau sudut), Delft, dan spesimen berbentuk sudut adalah yang paling umum digunakan (Long-Cheng Tang, Jin-Ping Peng, 2019).

\section{Ketahanan terhadap pengusangan/ageing test} untuk mengetahui ketahanan vulkanisat karet terhadap lingkungan yang bersifat panas. Ageing test juga disebut suatu proses mempercepat kerusakan untuk mengetahui ketahanan bahan terhadap pengaruh lingkungan.

\section{Pampatan Tetap}

Pampatan tetap merupakan salah satu parameter uji elastisitas suatu vulkanisat. Elastisitas adalah kemampuan suatu bahan untuk kembali ke bentuk semula setelah mengalami pembebanan. Pada kasus tertentu tempartur dibawah nol derajat dipergunakan untuk mengetahui reaksi pada kondisi ekstrim tertentu.

\section{Kekuatan ozon \\ Konsentrasi ozon $\left(\mathrm{O}_{3}\right)$ yang ada dalam lingkungan kerja dapat menyebabkan keretakan yang mendalam pada bahan elastomer, yang kemudian akan menyebabkan kegagalan komponen tersebut saat digunakan. Karet umumnya sangat rentan terhadap serangan ozon dan dapat menimbulkan efek besar pada}

\section{Ketahanan terhadap low temperature}

Semua elastomer akan mengalami beberapa jenis perubahan ketika berada pada temperatur rendah. Pada temperatur rendah material akan menjadi rapuh dan pecah pada saat ditekuk tiba-tiba atau saat terjadi benturan/impak.

\section{METODE PENELITIAN}

\section{Metode Penelitian}

Penelitian ini adalah penelitian ekspolaratif yaitu penelitian yang mengali informasi hasil penelitian-penelitian tentang pengaruh berbagai jenis mutu karet alam SIR 3L, SIR 5 , SIR 10, SIR 20 dan RSS terhadap mutu karet berbahan sintetis Neopren CRuntuk penggunaan bearing pad jembatan. Dalam 
penelitian yang menjadi pertimbangan pengaruh mutu karet alam dengan berbagai jenis dibandingkan dengan karet sintetis adalah dengan melihat mutu karet terhadap parameter uji sifat fisika.

\section{Tahapan dalam pengujian}

Pengujian sifat fisika vulkanisat umumnya dilakukan pada kondisi laboratorium suhu 20 30 oC dan kelembaban $50 \% \mathrm{RH}$. Contoh uji yang baru divulkanisasi disimpan 1 minimum 1 hari setelah vulkanisasi.Contoh uji kompon harus disimpan pada kondisi laboratorium tersebut minimul 1 jam sebelum dilakukan pengujian parameter fisika properties.

\section{Ke presisian data}

Untuk memastikan data uji dalam penelitian ini memberikan suatu ke presisian data, maka dilakukan batasan relatis standar deviasi yang tidak lebih besar dari $7 \%$. Jumlah sample uji dipergunakan 5 contoh.

\section{Metode uji}

Metode uji yang dipergunakan dalam penelitian ini mengacu pada SNI 3967:2008 dengan tiap-tiap parameter uji merujuk pada acuan metode uji seperti dibawah ini:

\section{HASIL DAN PEMBAHASAN}

\section{Hasil Pengujian SIR dengan metode uji SNI 06-1903-2000}

Hasil pengujian keselurhan dari tiap-tiap parameter uji terlebih dahulu di lakukan selektif data dengan melakukan ke presisian data dengan tingkat keberterimaan yaitu RSD $<7 \%$. Data yang tidak presisi di buang untuk menghindari terjadinya bias data dan yang akan menyebabkan bias hasil uji dan analisis.

Tabel 1. Pengujian mutu SIR dengan berbagai jenis karet SIR

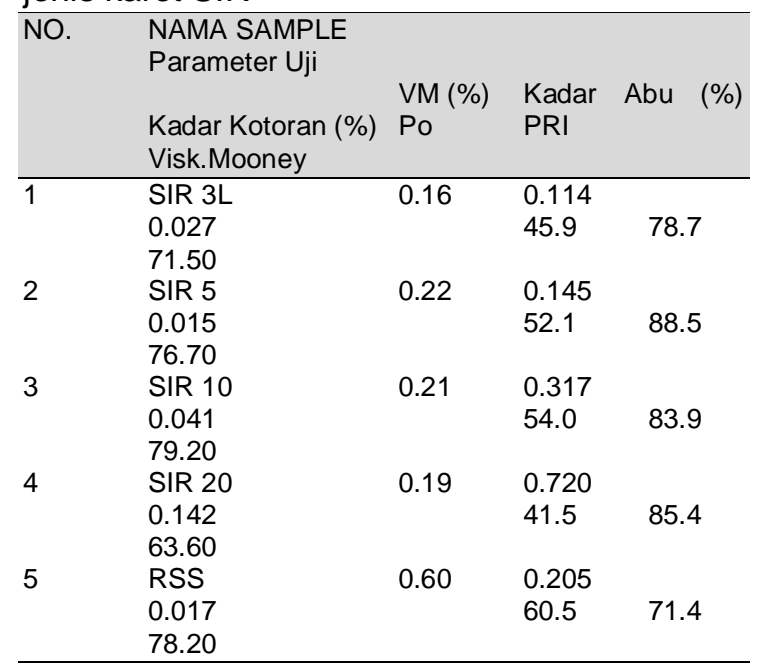

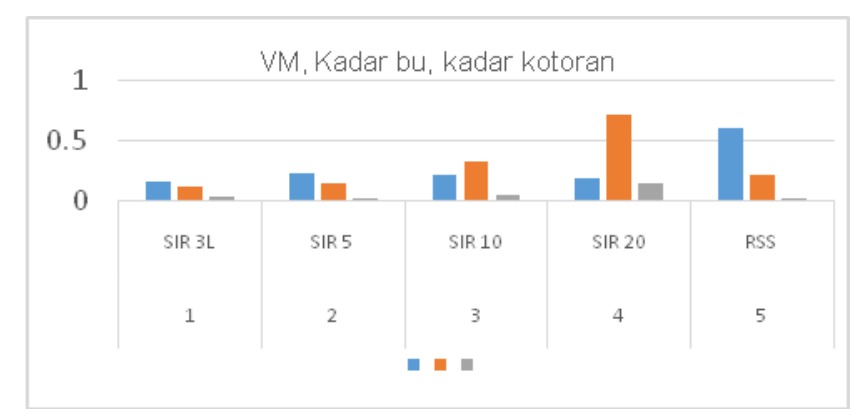

Gambar grafik 1 pengujian parameter volatile meter, kadar abu dan kadar kotoran

Dari hasil pengujian mutu karet alam dengan berbagai jenis memperlihatkan karet alam SIR 20 memiliki kadar abu yang paling tinggi dengan prosentase $0.720 \%$ dan diikuti oleh karet alam SIR 10 dengan prosentase kadar abu $0.317 \%$ dan yang terendah terdapat pada karet alam SIR 3L dengan prosentase kadar abunya $0.16 \%$,

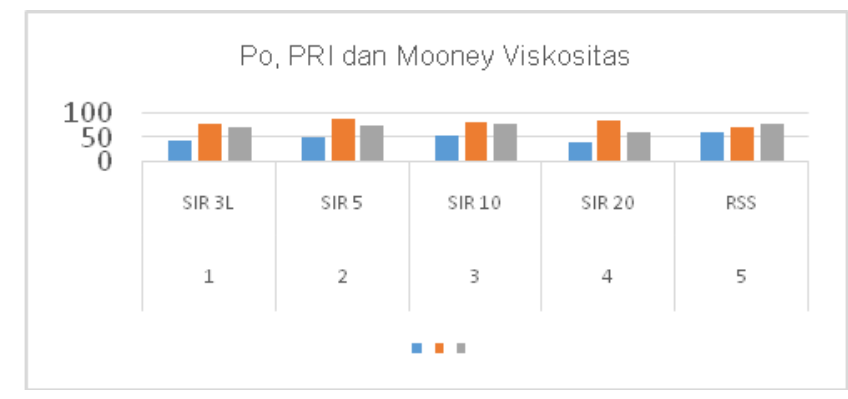

Gambar 2. Pengujian parameter plastisitas awal, plastisitas rate index dan viskositas mooney

Hasil pengujian paramtere Plastisitas awal (Po) pada table diatas memperlihatkan karet Rubber smoke sheet (RSS) mendapatkan nilai plastisitas awal yang tinggi dibandingkan dengan karet lainnya dan yang terendah untuk nilai Po terdapat pada karet alam SIR 20. Untuk parameter uji PRI, karet alam SIR 5 memberikan nilai tertinggi dengan nilai PRI 88.5, dan diikuti oleh karet alam SIR 20. Karet alam RSS memberikan nilai PRI terendah dengan nilai 71.4. Pada parameter uji viskositas mooney, nilai tertinggi didapat pada karet alam SIR 20 dengan nilai 79.20 dan di ikuti oleh karet RSS dengan nilai 78.20. Nilai terendah didapat oleh karet SIR 3L dengan nilai 71.50

Nilai Plastisitas Rate Index (PRI) diartikan sebagai kemampuan karet mengalami nilai plastisitas terhadap 
perubahan temperature. Makin tinggi nilai PRI maka semakin tinggi nilai tegangan putus dan rebound resilience, serta semakin rendah kalor timbul dari karet (Martosugito, 1989).

Table 2 Density karet kompond dengan berbagai jenis bahan karet alam dan sintetis

\begin{tabular}{lll}
\hline NO. & NAMA SAMPLE & DENSITY \\
\hline 1 & SIR 3L & 1.140 \\
2 & SIR 5 & 1.135 \\
3 & SIR 10 & 1.129 \\
4 & SIR 20 & 1.128 \\
5 & RSS & 1.133 \\
6 & Neoprene CR & 1.112 \\
\hline
\end{tabular}

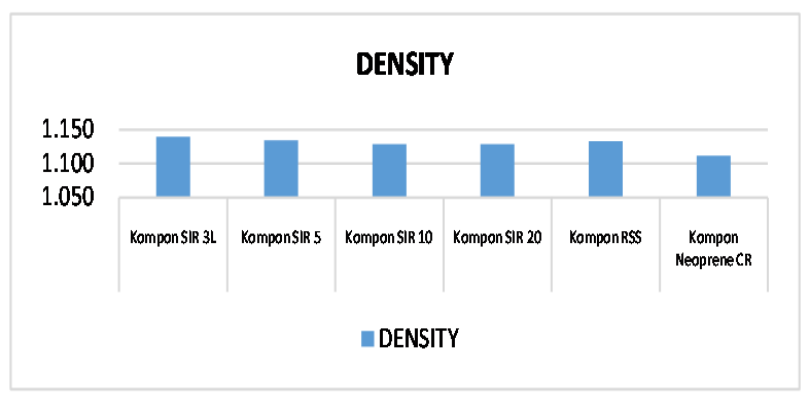

Gambar 3 Density karet kompond dengan jenis bahan karet alam dan sintetis

Karakteristik density karet alam dan karet sintetis tidak terlalu memiliki perbedaan yang signikan, hal ini dapat dilihat pada gambar grafik diatas dimana nilainya hanya berbeda sedikit satu dengan lainnya. Untuk nilai denity tertinggi didapat pada karet alam SIR 3L dikuti dengan SIR 5 dan untuk terendah yaitu karet SIntetis Neoprane.

Tabel 3 Kekerasan karet dan perubahan terhadap ageing dan low temperature

\begin{tabular}{|c|c|c|c|c|}
\hline No. & $\begin{array}{c}\text { Nama } \\
\text { Sample }\end{array}$ & $\begin{array}{l}\text { Kekerasan } \\
\text { (Shore A) }\end{array}$ & $\begin{array}{c}\text { Kekerasan } \\
\text { Setelah } \\
\text { Ageing (Shore } \\
\text { A) }\end{array}$ & $\begin{array}{c}\text { Kekeras } \\
\text { an } \\
\text { Setelah } \\
\text { Low } \\
\text { Tempera } \\
\text { ture -35 } \\
{ }^{\circ} \mathrm{C} \\
\text { (Shore } \\
\text { A) }\end{array}$ \\
\hline 1 & $\begin{array}{l}\text { Kompon } \\
\text { SIR 3L }\end{array}$ & 61 & +2 & +7 \\
\hline 2 & $\begin{array}{l}\text { Kompon } \\
\text { SIR } 5\end{array}$ & 60 & +2 & +6 \\
\hline 3 & $\begin{array}{l}\text { Kompon } \\
\text { SIR } 10\end{array}$ & 56 & +2 & +5 \\
\hline 4 & $\begin{array}{l}\text { Kompon } \\
\text { SIR } 20\end{array}$ & 52 & +2 & +11 \\
\hline 5 & $\begin{array}{l}\text { Kompon } \\
\text { RSS }\end{array}$ & 58 & +1 & +6 \\
\hline 6 & $\begin{array}{l}\text { Kompon } \\
\text { Neopren } \\
\text { e CR }\end{array}$ & 66 & +2 & +2 \\
\hline
\end{tabular}

Tabel Kekerasan Tipe Kompon Karet Alam dan Sintetis

100

0

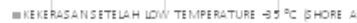

Gambar 4 Kekerasan karet dan perubahan terhadap ageing dan low temperature

Hasil kekerasan dengan karet sintetis lebih tinggi dibandingkan dengan karet alam lainnya. Karet alam kekerasan tertinggi terdapat pada karet alam SIR $3 \mathrm{~L}$ dengan nilai kekerasan 61 dan SIR 5 dengan nilai kekerasan 60. Nilai kekerasan terendah terdapat pada karet alam SIR 20.

Tabel 4 Kuat sobek dan perubahan terhadap ageing dan low temperature

\begin{tabular}{ccccc}
\hline No. & $\begin{array}{c}\text { Nama } \\
\text { Sample }\end{array}$ & $\begin{array}{c}\text { Ketahanan } \\
\text { Sobek } \\
\text { N/Mm }\end{array}$ & $\begin{array}{c}\text { Ketahanan } \\
\text { Sobek (Low } \\
\text { Temperature- } \\
\text { 35) N/Mm }\end{array}$ & $\begin{array}{c}\text { Kenaikan/Penurunan } \\
\text { Kuat Sobek (\%) }\end{array}$ \\
\hline 1 & $\begin{array}{c}\text { Kompon } \\
\text { SIR 3L }\end{array}$ & 7.38 & 8.46 & +14.65 \\
2 & $\begin{array}{c}\text { Kompon } \\
\text { SIR 5 } \\
\text { Kompon } \\
\text { SIR 10 }\end{array}$ & 6.87 & 7.59 & +10.56 \\
4 & $\begin{array}{c}\text { Kompon } \\
\text { SIR 20 } \\
\text { Kompon } \\
\text { RSS }\end{array}$ & 7.38 & 9.51 & +1.39 \\
6 & $\begin{array}{c}\text { Kompon } \\
\text { Neoprene } \\
\text { CR }\end{array}$ & 7.04 & 7.20 & +3.30 \\
\hline
\end{tabular}

ketahanan sobek untuk tipe kompon dengan bahan karet alam dan sintetis

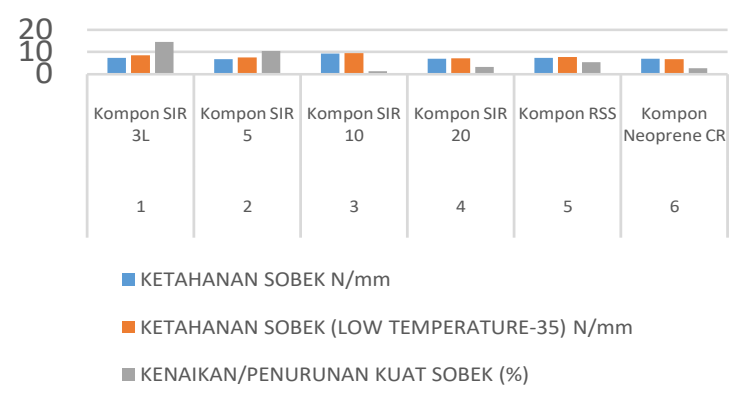

Gambar 5 Kuat sobek dan perubahan terhadap ageing dan low temperature

Data hasil pengujian kuat sobek menunjukkan nilai kuat sobek tertinggi terdapat pada kompon karet SIR10 dengan kuat Tarik yang cukup signifikan berbeda 
dengan jenis karet lainnya, yaitu dengan nilai kuat sobek $9.38 \mathrm{~N} / \mathrm{mm}$ dan nilai terendah terdapat pada karet SIR 5 dengan nilai 6.86
$\mathrm{N} / \mathrm{mm}$.sementaraitu untuk uji experiment kuat tarik terhadap suhu rendah, justru memperlihatkan nilai peningkatan kuat sobek.

Tabel 5 hasil pengujian kuat tarik dan perubahan terhadap ageing dan low temperature

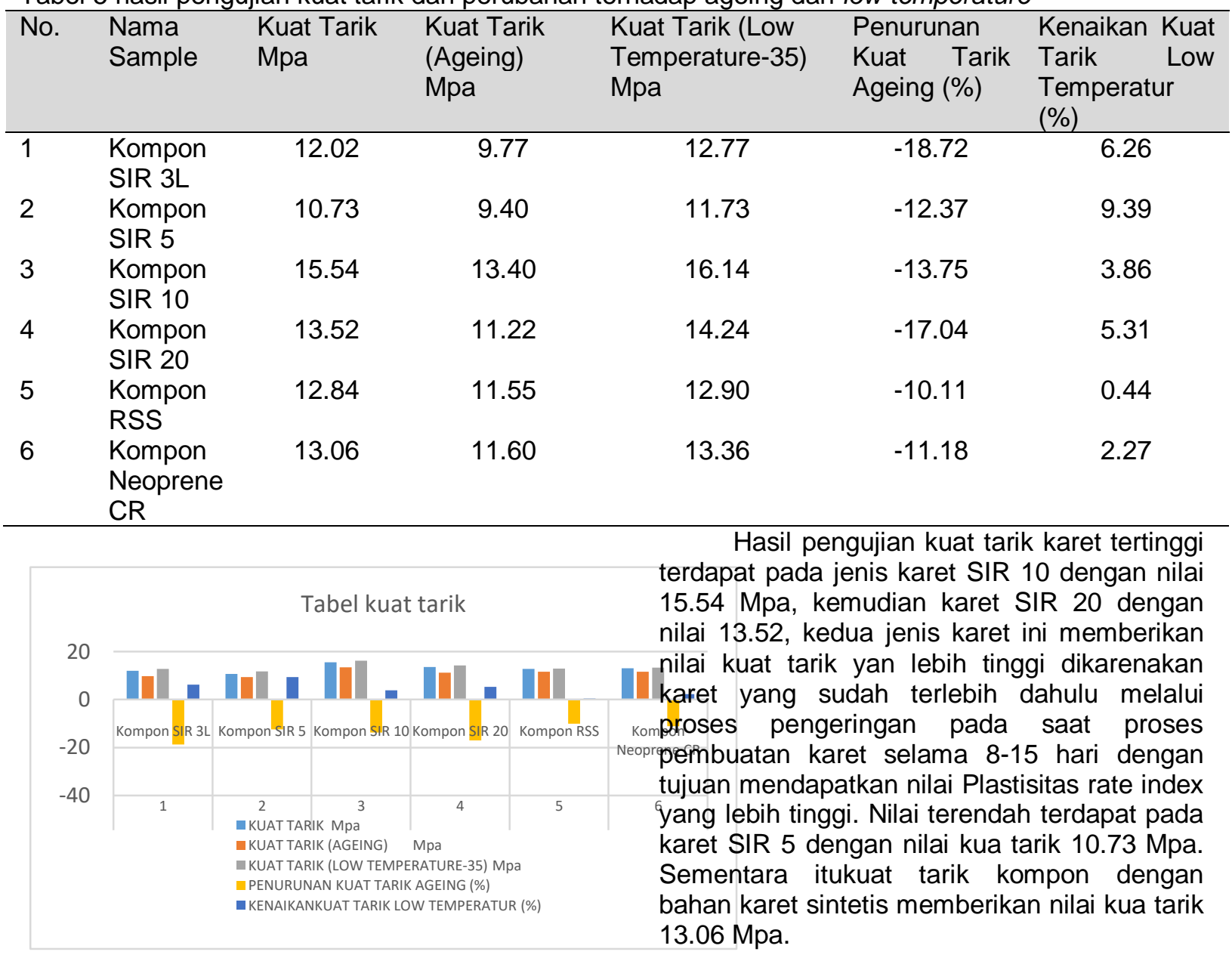

Gambar 6. Kuat tarik dan perubahan terhadap ageing dan low temperature

\begin{tabular}{ccccccc}
\hline No. & $\begin{array}{c}\text { Nama } \\
\text { Sample }\end{array}$ & $\begin{array}{c}\text { Perpanjang } \\
\text { an Putus } \\
(\%)\end{array}$ & $\begin{array}{c}\text { Perpanjang } \\
\text { an Putus } \\
\text { (Ageing) \% }\end{array}$ & $\begin{array}{c}\text { Perpanjangan } \\
\text { Putus (Low } \\
\text { Temperature-35) } \\
\%\end{array}$ & $\begin{array}{c}\text { Penurunan } \\
\text { Perpanjanga } \\
\text { n Putus } \\
\text { Ageing (\%) }\end{array}$ & $\begin{array}{c}\text { Kenaikan } \\
\text { Perpanjangan } \\
\text { Putus Low } \\
\text { Temperatur (\%) }\end{array}$ \\
\hline 1 & $\begin{array}{c}\text { Kompon } \\
\text { SIR 31 }\end{array}$ & 392.77 & 324.80 & 404.00 & -17.30 & 6.26 \\
2 & $\begin{array}{c}\text { Kompon } \\
\text { SIR 5 }\end{array}$ & 360.29 & 316.20 & 377.86 & -12.24 & 9.39 \\
3 & $\begin{array}{c}\text { Kompon } \\
\text { SIR 10 } \\
\text { Kompon } \\
\text { SIR 20 } \\
\text { Kompon } \\
\text { RSS }\end{array}$ & 494.62 & 441.00 & 530.64 & -10.84 & 3.86 \\
5 & 439.59 & 380.00 & 445.00 & -13.56 & 5.31 \\
\hline
\end{tabular}




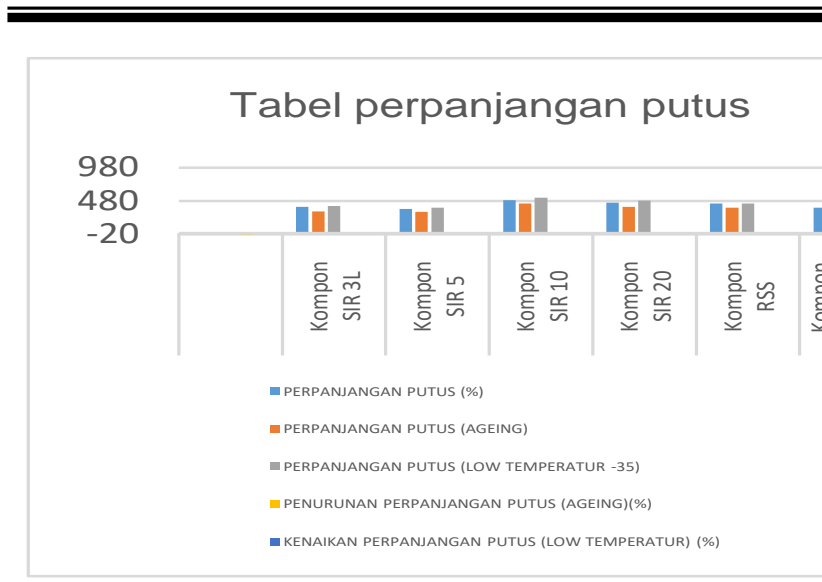

Hasil pengujian pampatan tetap pada grafik diatas memperlihatkan pampatan tetap tertinggi terdapat pada karet sintetis dengan nilai $31.00 \%$ dan terendah terdapat pada kompon karet SIR 3L dan kompon karet RSS. Hasil pengujian pampatan pada suhu rendah Timemperlihatkan hasil pampatan teringgi justru terjadi pada karet SIR $3 \mathrm{~L}$ dan terendah pada kompon karet sintetis, hal ini menjadikan posisi berlawanan hasil pada karakteristik kompon karet alam SIR 3L dengan sisntetis pada parameter uji pampatan suhu tinggi dan pampatan pada suhu rendah.

Gambar 7 perpanjangan putus dan perubahan terhadap ageing dan low temperature

Perpanjangan putus karet alam dan sintetis memperlihatkan karet alam SIR 10 memiliki nilai perpanjangan yang tinggi dengan nilai $494.62 \%$ dan yang terendah pada karet alam SIR 5 dengn nilai $360.29 \%$. Perubahan perpanjangan putus akibat pengaruh suhu tinggi terjadi pada karet alam SIR 3L dengan nilai $-17.30 \%$ dan yang terendah terjadi pada karet sintetis-6.63\%. Untuk nilai perubahan perpanjangan putus pada suhu rendah justru menunjukkan peningkatan perpanjangan,dan yang mengalami peningkatan tertinggi terjadi pada karet alam SIR 5 dan yang terendah pada karet alam RSS.

Tabel 7 Pampatan tetap dan perubahan terhadap ageing dan low temperature

\begin{tabular}{llll} 
No. & Nama Sample & $\begin{array}{l}\text { Pampatan Tetap } \\
\text { (Ageing) } \%\end{array}$ & $\begin{array}{l}\text { Pampata } \\
\text { n Tetap } \\
\text { (Low } \\
\text { Tempera } \\
\text { ture-35) } \\
\%\end{array}$ \\
\hline 1 & & & 16.28 \\
2 & Kompon SIR 3L & 21.32 & 14.14 \\
3 & Kompon SIR 5 & 25.27 & 15.67 \\
4 & Kompon SIR 10 & 29.03 & 13.41 \\
5 & Kompon SIR 20 & 28.67 & 14.81 \\
6 & Kompon RSS & 23.68 & 8.46 \\
& CR & 31.00 & \\
\hline
\end{tabular}

Tabel 8 Hasil pengujian abrasi

\begin{tabular}{lll}
\hline No. & Nama Sample & Abrasi $\left(\mathrm{Mm}^{3}\right)$ \\
\hline 1 & Kompon SIR 3L & 283.345 \\
2 & Kompon SIR 5 & 286.985 \\
3 & Kompon SIR 10 & 268.736 \\
4 & Kompon SIR 20 & 275.408 \\
5 & Kompon RSS & 259.555 \\
6 & Kompon Neoprene CR & 209.739 \\
\hline
\end{tabular}

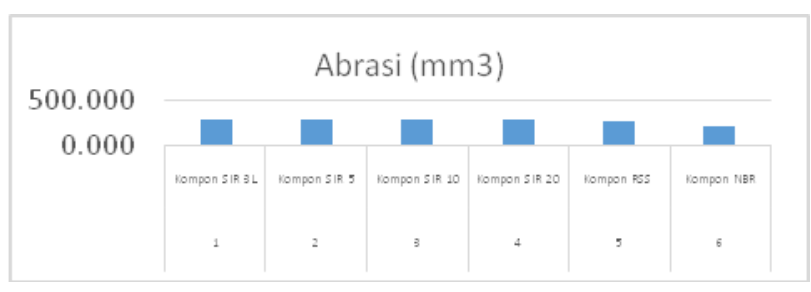

Gambar 9. Abrasi kompon karet natural dan sintetis

Dari hasil pengujian abrasi terdapat hasil dimana kompon dengan bahan karet sintetis neoprene mengalami pengikisan yang lebih banyak dibandingkan dengan kompon bahan karet alam, dengan nilai abrasi 209.739 $\mathrm{mm}^{3}$. Kompon dengan bahan baku karet alam yang mengalami abrasi yang tertinggi terjadi pada kompon dengan bahan karet RSS dan SIR 10. Dengan melihat hasil pengujian parameter Mooney viskositas yang menunjukkan karakteristik kemampuan suatu

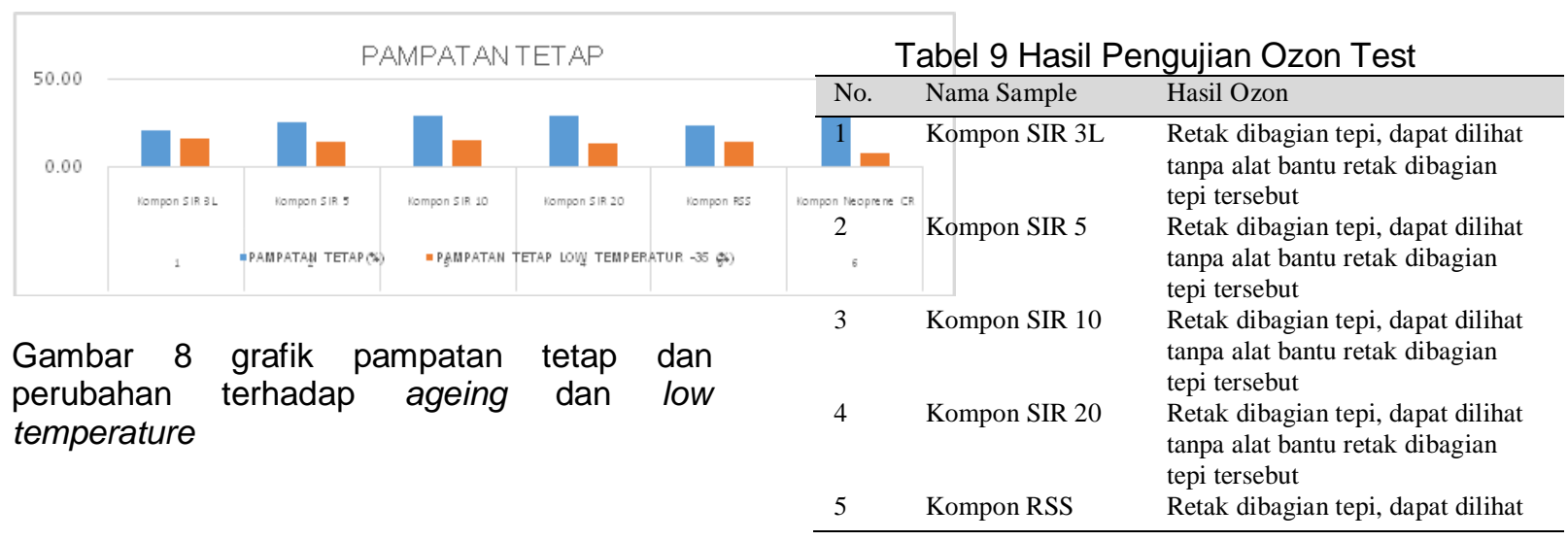




\begin{tabular}{lll}
\hline No. & Nama Sample & Hasil Ozon \\
\hline & & $\begin{array}{l}\text { tanpa alat bantu retak dibagian } \\
\text { tepi tersebut } \\
\text { Tidak retak }\end{array}$ \\
& $\begin{array}{l}\text { Kompon } \\
\text { Neoprene CR }\end{array}$ & \\
\hline
\end{tabular}

Dari hasil pengujian ozon test menunjukkan semua kompon karet yang berbahan karet alam mengalami crack yang terlihat dengan mata telanjang pada sisi pinggir sample dan sementara itu untuk kompon bahan karet sintetis menunjukkan hasil yang lebih kuat terhadap paparan ozon.

\section{KESIMPULAN}

Hasil pengamatan dari pengujian beberapa parameter uji menunjukkan hasil sebagai berikut:

a) Parameter density menunjukkan hasil tidak terlalu ada perbedaan diantara kompon berbahan karet alam dan kompon berbahan karet sintetis tidak terdapat perbedaan signifikan dengan density diantara 1.112 sampai dengan 1.140

b) Kekerasan karet dari hasil pengujian memperlihatkan karet sintetis memiliki kekerasan tertinggi dengan nilai 66 dan terendah pada kompon karet alam SIR 52, sementara itu untuk perubahan kekerasan rata-rata semua kompon karet mengalami peningkatan kekerasan +2 , untuk peningkatan kekerasan kompon karet pada temperature rendah terjadi pada kompon karet alam SIR 20dengan peningkatan + 11 dan terendah pada kompon karet sintetis + 2 , yang artinya menunjukkan kestabilan pada suhu tinggi dan rendah.

c) Parameter uji ketahann sobek menunjukkan hasil kekuatan sobek tertinggi terjadi pada kompon karet SIR 10 dengan nilai 9.38 dan terendah pada kompon karet alam SIR 5. Sementara itu untuk pengaruh temperature rendah $-35{ }^{\circ} \mathrm{C}$ pada kuat sobek menunjukkan kenaikan pada semua kompon, baik itu alam dan sintetis. Kenaikan tertinggi kuat sobek pada temperature rendah terjadi pada kompon karet alam SIR $3 \mathrm{~L}$ dengan nilai +16.65 dan terendah pada kompon karet SIR 10 dengan nilai +1.39 dan kompon karet sintetis dengan nilai +2.75

d) Parameter kuat tarik tertinggi terjadi pada kompon karet alam SIR 10 dengan nilai kuat tarik $15.54 \mathrm{Mpa}$ dan hanya jenis kompon karet ini yang memenuhi persyaratan bantalan elastomeric. Sementara itu untuk penurunan kuat tarik tertinggi terjadi pada kompon karetSIR 3L dengan nilai $-18.72 \%$ dan terendah pada karet RSS dengan nilai $-10.11 \%$. Secara umum perubahan kuat tarik dengan ageing untuk semua jenis kompon karet alam dan sintetis memenuhi persyaratan. Sementara itu untuk pengaruh kuat tarik pada temperature rendah justru menunjukkan kenaikan kuat tarik, dan nilai tertinggi terjadi pada pada kompon karet alam SIR 5

e) Parameter perpanjangan putus tertinggi terjadi pada kompon karet alam SIR 10 dan kompon karet SIR 20 dan terndah terjadi pada kompon karet SIR 5.Perubahan perpanjangan putus akibat pengaruh suhu tinggi terjadi pada karet alam SIR 3L dengan nilai $-17.30 \%$ dan yang terendah terjadi pada karet sintetis $-6.63 \%$. Untuk nilai perubahan perpanjangan putus pada suhu rendah justru menunjukkan peningkatan perpanjangan, dan yang mengalami peningkatan tertinggi terjadi pada karet alam SIR 5 dan yang terendah pada karet alam RSS

f) Parameter pampatan tetap memperlihatkan hasil dimana karet sintetis mengalamipampatan tertinggi dengan nilai $31 \%$ dan terendah terjadi pada kompon karet alam SIR 3L. Hasil pampatan memperlihatkan karakteristik karet alam lebih baik dalam pampatan terhadap temperature tinggi, sementara itu pada temperature rendah, nilai terendah justru terjadi pada kompon karet sintetsi dengan nilai 8.46, dan tertinggi pada kompon karet alam SIR 3L dengan nilai $16.28 \%$. Diisimpulkan karet alam unggul pada suhu tinggi dan karet sintetis unggul pada suhu rendah untuk parameter pampatan tetap. Berdasarkan persyaratan mutu bantalan elastomeric, semua jenis kompon memenuhi persyaratan mutu.

g) Parameter ozon memperlihatkan bahwa keseluruhan kompon karet alam dan sintetis mampu tahan terhadap paparan ozon

h) Secara keseluruhan karet alam masih lebih baik dibandingkan dengan karet sintetsi untuk beberapa pamater, diantaranya kuat tarik, perpanjangan putus, pampatan tetap. Sementara itu kompon karet sintetis memiliki kekuatan pada kemapuan ketahanan aging dan kestabilan pada suhu rendah.

\section{SARAN}

a) Perlu dilakukan penelitian dengan kombinasi kompon karet alam dengan berbagai jenis campuran diantara karet alam, untuk mendapatkan nilai kemampuan 
ideal yang memenuhi karakteristik persyaratan mutu bantalan elastomeric

b) Perlu dilakukan penelitian dengan kombinasi berbagai jenis karet sintetis untuk melihat sejauh mana kemampuan dan kekuatannya terhadap parameterparameter seperti yang ditetapkan pada persyaratan mutu bantalan elastomerik

c) Perlu dilakukan penelitian dan pengujian mutu kombinasi ideal untuk campuran kompon karet alam dan kompon karet sintetis terhadap persyaratan mutu banatalan elastomeric

\section{UCAPAN TERIMAKASIH}

Team peniliti mengucapkan terima kasih kepada:

a) Tuhan Yang Maha Pengasih dan Kuasa, atas segala berkat dan karunia yang diberikan kepada tema penulis sehingga kami senantiasa diberi semangat dan motivasi untuk menyelasikan tulisan tersebut

b) PT. DJawati Cilacap, atas bantuan dan kerjasamanya dalam proses pembuatan dan pembelian karet alam SIR 3L, SIR 5 dan SIR 10

c) PT. Pratama Rubber, khususnya kepada team Pak Sahidan, atas bantuan dan kerjasamanya dalam pembuatan karet compound

d) Kepala Balai Pengujian Mutu Barang, Ibu Dyah Palupi atas dukungannya dalam pengujian sample penelitian karet kompon.

e) Kepada team analisis pengujian lab FisikaMekanik, khususnya pada lab uji karet dan mekanik

\section{DAFTAR PUSTAKA}

Abu Hasan, Rochmadi, Hary Sulistyo, Suharto Honggokusumo, 2017. The Effect of Ingredients Mixing Sequence in Rubber Compounding upon Vulcanization Kinetics of Natural Rubber: An Autocatalytic Model Study.

Achmad fariz sahly, Fakultas Teknologi Pertanian, IPB, 2006, pembuatan perekat karet pada

logam menggunakan campuran karet siklo dan karet alam.

Agung Rohmad1, Heru Sukanto2, Wijang Wisnu Raharjo2, Volume 11 Nomor 2, Maret 2013. Karakterisasi produk ubin berbahan dasar plastik pp dan karet ban bekas dengan metode pressured sintering.
Ali Farida, 2010. Jurusan Teknik Kimia Fakultas Teknik Universitas Sriwijaya. "Koagulasi lateks dengan ekstrak gadung".

Ari Sugiyanto, Jurusan Teknik Mesin Fakultas Teknik, Universitas Muhammadiyah Surakarta, 2013, pengaruh Sulfur Terhadap Kekerasan Produk (Rubber Bushing) Dengan Perbedaan Jumlah Sulfur 8gram, 10gram Dan 12gram

Badan Standard Nasional, 2000. Standar Nasional Indonesia 06-1903-2000.

Toha Juniawaty, et al, 2008. Balai Penilitian Tanaman Industri dan Penyegar. "Pemanfaatan asap cair kayu karet dan tempurung kelapa untuk penanganan polusi udara dan lump".

Bahruddin, Sumarno, G. Wibawa dan N. Soewarno, Reaktor, Vol. 11 No.2, Desember 2007, Hal. : 71-77, Morfologi dan properti campuran karet alam/polypropylene yang divulkanisasi dinamik dalam internal mixer

Chobra kumbara sakti, teknik mesin, fakultas teknik, 2017, karakterisasi bahan karet sepeda motor terhadap kekerasan dan pengujian.

Hardiyanto Rizka, 2013. "Pemanfaatan sari mengkudu sebagai bahan pengumpal lateks".

Heru Sukanto, Jurnal IImiah Teknik Mesin CakraM Vol. 3 No. 1, Juni 2009 (57 61), PengaruhSuhu Sintering Terhadap Densitas dan Kekuatan Komposit Plastik - Karet

Hidayoko Ganif, Okta Wulandra, 2014. "Program Studi Teknologi Pertanian Fakultas Pertanian

Japanese Industrial Standard K 6301-1975, Physical Testing Methods for Vulcanized Rubber

Jenis dan kelebihan bahan karet, https://rubberchemtechnol.org/doi/abs/1 $0.5254 / 1.3542760$

Laola Septriani. Jurusan Teknik Kimia Fakultas Teknik Universitas Sriwijaya. "Pengaruh asam askorbat dari ekstrak nanas terhadap koagulasi lateks (studi pengaruh volume dan waktu pencampuran)".

L. S. Montagna and R. M. C. Santana, Plastics, Rubber and Composites 2012 VOL 41 NO 6, Influence of rubber particle size on properties of recycled thermoplastics containing rubber tyre waste

Muis Yugia, 2007. Departemen Kimia MIPA USU. "Pengaruh pengumpal asam asetat, asam formiat, dan berat arang tempurung kelapa terhadap mutu karet". 
Muhammad Alfatih Hendrawan, Pramuko IImu Purboputro, Jurusan Teknik Mesin Universitas Muhammadiyah Surakarta, Simposium Nasional Teknologi Terapan (SNTT)3 2015, studi karakteristik sifat mekanik kompon karet dengan variasi komposisi sulfur dan carbon black sebagai bahan dasar ban luar.

Nasruddin, 2018. Balai Riset dan Standardisasi Industri Palembang. Sifat mekanik rubber waves dari komposit karet alam dan karet sintesis menggunakan multi filler.

Norma Arisati Kinasih, Mohamad Irfan Fathurrohman, Dadang Suparto, majalah kulit, karet, dan plastik Vol. 31 No. 2 Desember Tahun 2015: 6574.Pengaruh suhu vulkanisasi terhadap sifat mekanis vulkanisat karet alam dan karet akrilonitril-butadiena

Nuur Laila Najwa Thajudin,Nur Syamsinar, Sardi Mohd Hafiz Zainol, Raa Khimi Shuib, Journal of Rubber Research. Room temperature self-healable natural rubber, https://link.springer.com/article/10.1007/ s42464-019-00025-8

Peraturan Menetri Perdagangan Republik Indonesia NOMOR: 10/MDAG/PER/4/2008, tentang Ketentuan Karet Alam Spesifikasi Teknis Indonesia (SIR) yang diperdagangkan ke Luar Negeri.

Permendag No.53/M.DAG/PER/10/2009 tentang pengawasan Mutu Bahan Olah Komoditi Ekspor Standar Indonesia Rubber yang Diperdagangkan.

Permendag No.54/M.DAG/PER/7/2016 tentang pengawasan Mutu Bahan Olah Karet Spesifikasi Teknis yang Diperdagangkan.

Popy Marlina dan Hari Adi Prasetya, 2017. Balai Riset dan Standardisasi Industri Palembang. Karakteristik karet sheet dengan bahan baku komposit modifikasi pati - lateks.

Purbaya Mila, 2011. Balai Penelitian Karet Sumbawa. "Pengaruh beberapa jenis bahan pengumpal lateks dan hubungannya dengan susut bobot, kadar karet kering dan plastisitas".

Rahmaniart, Gatot Priyanto dan Basuni Hamzah, Dinamika Penelitian BIPA VoL 20 No. 35 Tahun 2009, pembuatan kompon karet dengan penambahan minyak kemiri (9andlenut otll epoksi.

Ramadhani Fitria Afrianti, 2013. "Keragaman bakteri endofit pada kultivar nanasleor dan nanas duri di kabupaten subang".

Refrizon, S.Si, 2003. Fakultas Matematika dan IImu Pengetahuan Alam. "Viskositas mooney karet alam".

SNI Standard Indonesian Rubber (SIR) 061903-2000

SNI 06-2047-1998 Bahan Olah Karet (BOKAR) Lateks Kebun dan Gumpalan Lateks Kebun.

SNI 3967:2008, BSN, Spesifikasi bantalan elastomer tipe polos dan tipe berlapis untuk perletakan jembatan

Solichin M, Anwar A. 2003. "Pengaruh pengumpalan lateks, perendaman dan penyemprotan bokar dengan asap cair terhadap bau bokar, sifat mekanis dan sifat fisik vulkanisat".

Toha Juniawaty, ling Sobari. "Pengaruh pengumpalan dengan tawas".

UNIVED Bengkulu. Pengaruh pengunaan jenis bahan pengumpal lateks terhadap mutu SIR".

Wiwien Andriyanti, Darsono, Wisjachudin Faisal, Pusat Teknologi Akselerator dan Proses Bahan - BATAN, Yogyakarta, ISSN 0216 - 3128, Kajian metode vulkanisasi lateks karet alambebas nitrosamin dan protein allergen.

Weili Wu, Xiang Li, Journal of Rubber Research, Jan 1, 2019. Wear and thermal properties of carbon fiber reinforced silicone rubber/fluorine rubber composites

Yulita Eli, 2012. Balai Riset dan Standardisasi Industri Palembang. "Pengaruh asap cair serbuk kayu limbah industri terhadap mutu bokar". 